Esta publicación cientifica en formato digital es continuidad de la revista impresa ISSN-Versión Impresa 0798-1406 / ISSN-Versión on line 2542-3185Depósito legal pp
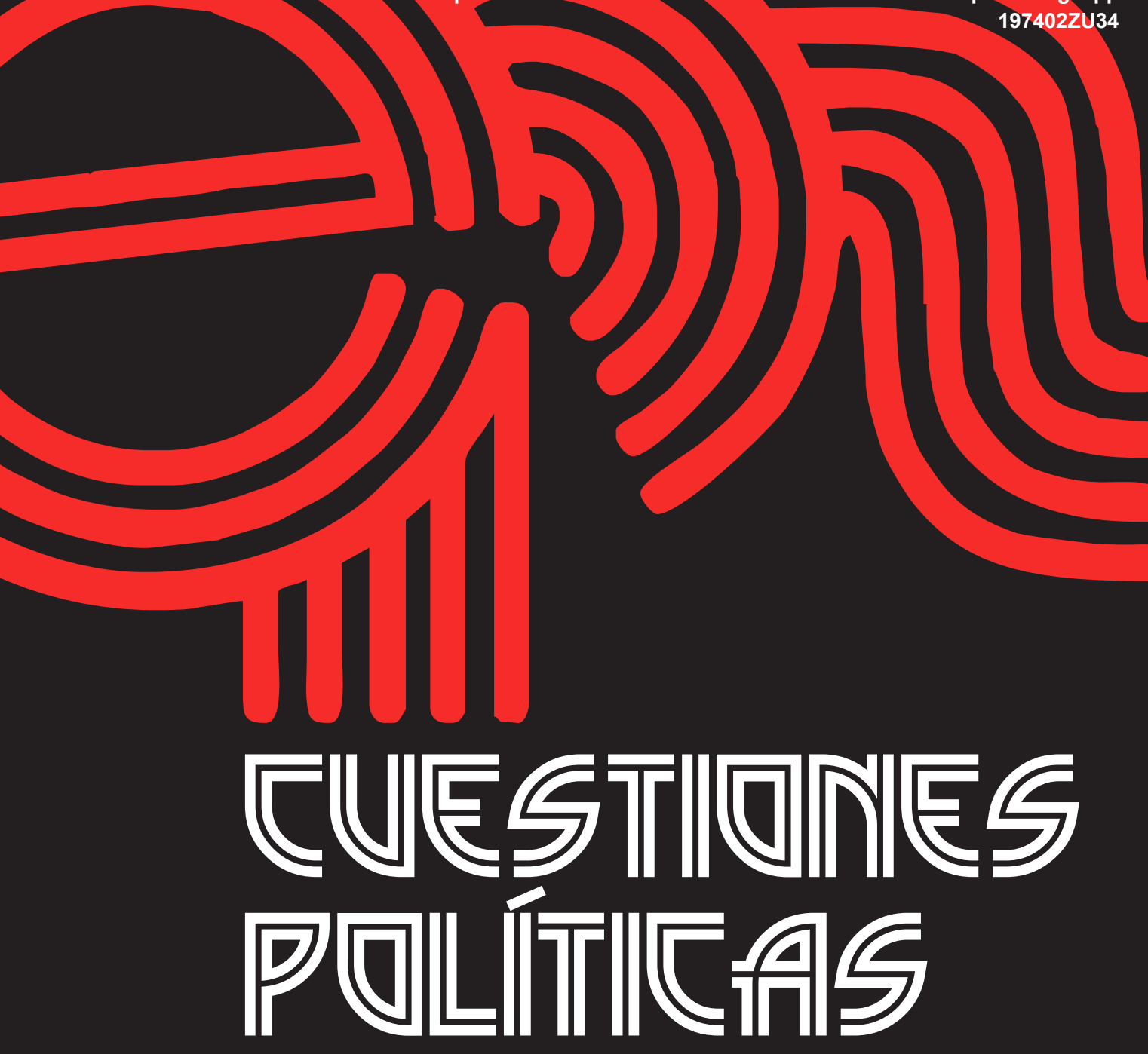

Instituto de Estudios Políticos y Derecho Público "Dr. Humberto J. La Roche" de la Facultad de Ciencias Jurídicas y Políticas de la Universidad del Zulia Maracaibo, Venezuela
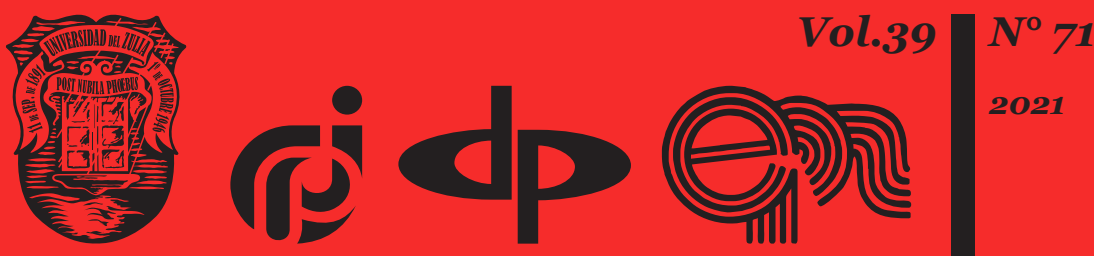


\title{
Legal procedure in roman law and its reflection in modern civil procedure
}

\author{
DOI: https://doi.org/10.46398/cuestpol.3971.56
}

\author{
Kravtsov Serhij * \\ Vlasenko Serhii ** \\ Rozhnov Oleh *** \\ Iryna Malinovska ****
}

\begin{abstract}
Tremendous efforts of legislators are directed towards the development of an ideal judicial system and procedure of administering justice. However, current trends of judiciary reformation are easier to comprehend and accept if we turn to the origins of legal protection of human rights which, undoubtedly, go back to the Roman law. Methodology: From this point we use comparing methods for analizing the legislative provisions; the structural method and historical method was used for the background of Legal procedure in roman law. Results and conclusions: In this article we will outline the main stages of formation of legal protection of human rights in Roman law and characterize types of these processes namely legis actiones, formulary procedure and cognitio. By analyzing the original sources that have survived to our times, namely the Law of Twelve Tables, Gaius `s Institutions and Justinian `s Digestes, we will examine what peculiarities of consideration and resolution of cases each of these stages demonstrated; how the traditional views on the behavior of the parties and the court in the process were established; which main requirements were applied to justice in civil matters in Roman law. In the course of the work the following methods were used: essential, comparative, general historical.
\end{abstract}

Keywords: legis actiones, formulary procedure, cognitio.

* PhD in Law, Associate Professor, Department of Civil Procedure, Yaroslav the Wise National Law University, Ukraine. ORCID ID: hhttps://orcid.org/oooo-0002-8270-193X. Email: s.o.kravtsov@nlu. edu.ua

** Associate professor of the Department of Legal History, Yaroslav Mudryi National Law University. ORCID ID: https://orcid.org/ oooo-0oo1-7696-6096. Email: s.i.vlasenko@nlu.edu.ua

*** PhD in Law, Assoc. Prof. at Civil Procedure Department Yaroslav Mudryi National Law University Kharkiv, Ukraine. ORCID ID: https://orcid.org/ oooo-0002-7217-8153. Email: o.v.rozhnov@nlu.edu. ua

**** PhD. In Law, Assist. Prof. of Civil Law Department, Yaroslav Mudryi National Law University Kharkiv, Ukraine. ORCID ID: https://orcid.org/oooo-0001-5945-2042. Email: i.malynovska@knute.edu.ua 


\section{Procedimiento legal en derecho romano y su reflexión en el procedimiento civil moderno}

\section{Resumen}

Los tremendos esfuerzos de los legisladores se dirigen hacia el desarrollo de un sistema judicial ideal y un procedimiento de administración de justicia. Sin embargo, las tendencias actuales de reforma judicial son más fáciles de comprender y aceptar si nos dirigimos a los orígenes de la protección jurídica de los derechos humanos que, sin duda, se remontan al derecho romano. Metodología: A partir de este punto utilizamos métodos comparativos para analizar las disposiciones legislativas; El método estructural y el método histórico se utilizaron para el trasfondo del procedimiento legal en derecho romano. Resultados y conclusiones: En este artículo describiremos las principales etapas de formación de la protección jurídica de los derechos humanos en el derecho romano y caracterizamos los tipos de estos procesos, a saber, legis actiones, formulario de procedimiento y cognitio. Analizando las fuentes originales que han sobrevivido hasta nuestros días, a saber, la Ley de las Doce Tablas, las Instituciones de Cayo y los Digestes de Justiniano, examinaremos qué peculiaridades de la consideración y resolución de casos demostró cada una de estas etapas; cómo se establecieron las opiniones tradicionales sobre el comportamiento de las partes y del tribunal en el proceso; qué requisitos principales se aplicaban a la justicia en materia civil en el derecho romano. En el curso del trabajo se utilizaron los siguientes métodos: esencial, comparativo, histórico general

Palabras clave: legis actiones, procedimiento de formulario, cognitio.

\section{Legal Procedure in Roman private law}

Roman law received its second name - "the law of action" because Roman lawyers acknowledged only those things that had an action for its provision as law. The Roman people, like many others, had experienced the era of private savage punishment of violators of law before the creation of a state court. Everyone who considered his right to be violated took the law into his own hands with those who inflicted an offense. The most common ways of protecting rights were self-defence and arbitrariness, which, in fact, were examples of blood revenge since the victim himself was the judge.

The transition from private punishment to state court trials was gradual. At first, the rules of use of violence against the offender were established; then the alternative in form of redemption for crime was suggested. It was foremost caused by the fact that state authorities began to pay significant attention to the internal state structure. Sorting out relations between private persons and their families became an undesirable phenomenon. 
It is worth noting that Roman lawyers didn't have special science of civil process and didn't single it out as a separate branch of law. The word "processus" was never used by Romans in the sense which it has in the modern law. In the works of Gaius and Justinian, the teaching of civil law and legal proceedings is one entity. For example, in the Laws of Twelve Tables, the first tables are devoted to the issues of legal procedure, and the structure of the Gaius Institutions reflects the significance of legal proceedings and the protection of rights.

The judicial procedure of the protection of rights in Rome went through three stages in its development, reflecting the following forms:

1) legis actiones;

2) formulary procedure, which were together called the ordinary processes,

3) and cognitio or extraordinary.

The first process received its name from legis actiones, which translates from Latin as "lawsuits" and dates from the period preceding the publication of the Laws of Twelve Tables and until the middle of the 2nd century BC.

The formulary procedure received its name from the formula of the praetor or per formulas in Latin and for some time coexisted with legis actiones. It corresponds to the time of classical period of Roman law, since it was used from the middle of the 2nd century B.C. till the 3 rd century BC.

Legis actiones and formulary procedure were carried out in two phases: the first phase, during which the action took place in the presence of the magistrate, and the second phase, which took place in the presence of a judge. This was the usual order of consideration of the case, therefore these processes are called ordinary.

The formulary procedure was used in jurisprudence until the time of Dominat, and it finally disappeared from the courts in 342, under the constitution of Constance and Clement.

In contrast to ordinary processes, the cognitio procedure (extraordinaria cognition) was carried out only in the presence of a magistrate, that is, a public official, so it was called extraordinary. It was in practice in Rome and Italy from the time of August and began to be actively developed under Andrian when the emperor delegated the consul or other magistrate the right to interfere in certain affairs that affected the interests of individuals.

All these litigations have become a reflection of the aspirations of society and the state policy of protecting rights. It is in them that the basic procedures and rules for the administration of justice have been formed, which are still considered traditional in the countries which were recipients of Roman law. 

924
Kravtsov Serhij, Vlasenko Serhii, Rozhnov Oleh y Iryna Malinovska
Legal procedure in roman law and its reflection in modern civil procedure

\section{Ordinary Roman lawsuits: legis actionem and per formulas}

The main source (although incomplete) of information about the ancient civil process in Rome is the Roman lawyer Gaius, who considers the issue in the fourth book of his work "Institutiones" - Institutions. Gaius reports that the oldest form of the civil process in Rome was the so-called legis actiones. (I. 4. 11)

Gaius ambiguously expresses what exactly "Lege agere" means: either it is to file a legal claim, which means "certis verbis agere", or to file a lawsuit with certain fixed and unchangeable words.

The filing of a claim is not permitted, unless otherwise provided by law or nulla legis actio sine lege. This is the most significant feature of the legislation process, which will later become the main reason for its replacement with a formulary showing its excessive formalization. According to J. Pokrovsky, "lege agree" in ancient times simply meant "to act, to exercise the right in a lawful way, in opposition to violence" ${ }^{5}$. Consequently, the process was called legis actiones.

To begin the process, the mandatory condition was the personal presence of both the plaintiff and the defendant. In this case, the question is how to force the defendant to appear in court, as his absence would prevent the process. A characteristic feature of Old Roman law is that the state power itself did not summon the defendant and did not force him to appear. It was the plaintiff who had to bring the defendant. To this end, the plaintiff was provided with a tool such as in jus vocation (summons to court). The first resolutions of the laws of the Twelve Tables were devoted to this matter.

Legis actiones procedure is based on strict formalism and complex rituals, with the use of certain gestures, words, and special verbal formulas.

The process consists of two stages: in jure and in judicio.

The purpose of the in jure stage was to establish exclusively the legal side of the case, which is the existence of a claim and compliance with the procedure associated with it. This stage took place before the magistrate, which was endowed with the relevant jurisdiction (juristio - from the words jus dicere - "say the right", i.e. to apply the legal rules). First spoke the consul, then the praetor (peregrinus for disputes with foreigners and urbanus for disputes between the Romans), and aedile in the event of disputes related to the market. The parties had to appear in person, as the representation was not allowed, and nobody could act on behalf of another person (or lat. Nemo alieno nomine agere potest). This stage ended with the magistrate appointing a judge for its consideration, having established the conformity of the brought suit with its established form in the law, and the case went to the second stage. 
The stage in judicio was devoted to solving another task, which is verification of the actual part of the case. This task was performed either by a permanent board or a specially created jury for the case, or a judge (individually), or an arbitrator selected by the parties. The process ended with making a decision (sententia), which concluded the dispute between the parties.

Gaius stated that there are five basic forms of legis actio or five types of lawsuits that are brought in accordance with the law (lege autem agebatur modis quinquae).

\section{Legis actio per sacramentum.}

In essence, it is a process in the form of a bet, when by expressing the claim, the plaintiff contributed a certain amount of money (sacramentum) and demanded that the defendant would spend the same amount. Since only one of the parties can be favoured in the dispute, its sacramentum is considered just, and the one given by the other party is unjust (utrius sacramentum justum sit, utrius injustum).

This means that legitimate doubts about the encroachment of one party smoothly transferred the process from material to personal - legis actio sacramento in personam, which, unfortunately, remained unknown to us. The winning party in the process was the one whose sacramentum was considered just, while sacramentum made by the other party was charged to the proceeds of the treasury. Various private disputes could be resolved in the form of legis actio, except those for which independent claims were foreseen (I. 4.13).

The general form acquired certain characteristics depending on whether it was about belonging to a particular thing (actio in rem) or about the liability of the defendant to the plaintiff (actio in personam).

1) Actio in rem manifests in a dispute about the seizure of things by one person from another. Under the rules, the property on dispute was delivered to the magistracy. If the thing was something that was hard to deliver, then some part of it was necessary to be brought (for example, a sheep from the disputed flock). If the subject of the dispute was a piece of land, then some amount of its soil was brought, which performed exclusively ritual functions (I. 4.17).

This norm can be explained by the presence of several logical reasons. First, the court proceedings, without the certainty that the thing really exists, and one of the parties owns it, makes the court absurd, since the main purpose of the appeal was not the conduct of the court proceedings, but the establishment of fairness by a court decision, for example, the transfer of the thing to its owner. Secondly, this thing, available at the moment of the 
beginning of the dispute, could disappear and thereby render the whole process pointless, so it was necessary to solve its fate at the time of the dispute. This norm can be considered a prototype of the modern institute for the provision of claims.

The plaintiff, holding in his hands a spear called vindicta, proclaimed a precisely defined formula: Hanc ego rem exjure Quiritium rneam esse ajo; sicut dixi ecce tibi vindictam imposui! - I claim that this thing belongs to me according to the right of quirts, in affirming this, I impose a vindict! This moment of affirmation of the right to a thing is called lat. vindicatio, hence the legal ways to protect the right to claim are called vindicatory. In response, contrvindicatio took place - the implementation of similar actions and the declaration of the same words by the defendant. Then the praetor ordered both parties to leave the thing and each party introduced sacramentum at the request of the other, and the praetor transferred the thing to the temporal use of the plaintiff or defendant for the resolution of the dispute. Everything that happened was recorded and witnessed by the people present (litis contestatio). This concluded the stage in jure and the in judicio stage began. The parties, with the participation of the magistrate, chose a private judge who then resolved the dispute and made a decision without the participation of state authorities. For the conduct of the second stage there were no forms or rituals. Party statements and provision of evidence happened in a free form.

2) Actio in personam is less known, because the full description of the ritual of this case was lost. It is likely that the plaintiff started with the statement "Ajo te mihi centum dare oportere", which is, "I claim that you must pay me 100"; the defendant denied with "nego me tibi centum dare oportere" ("I deny that I owe you 100"). Then the process took place in the order indicated earlier.

\section{Legis actio per manus injectionem.}

This type of procedure was used to collect debts. In order to do this, the creditor delivered the debtor to the magistrate, declared his debt in verbal form and laid the hand (manus) on the debtor (hence the name of the form). The debtor himself could not dispute his debt. This could be done for him by another person, who would be called vindex, i.e. a person, who, in fact, vouched for the debtor and risked to pay the plaintiff double amount of money (in duplum) if the contestation failed to succeed. In the absence of a vindex the debtor was brought at the creditor `s disposal. The law of the Twelve Tables gave the debtor 30 days to pay the debt, the failure of which could lead to debtor`s dissection (Table III of the Law of Twelve Tables ).

Discussions about the application of this law are still on-going but no one better than Shakespeare in The Venice Merchant succeeded to describe its essence. 
Petelius law of $326 \mathrm{BC}$ substantially limited the Law of Twelve Tables by abolishing the right of the creditor to sell and kill the debtor. At the time of Julius Caesar, legislation was reformed and, according to T. Mommsen "a large legal principle was proclaimed, claiming that freedom does not depend on property, but is the primordial right of a person, which can be taken by a state only from the criminal, but not from the debtor"'.

\section{Legis actio per pignoris capionem.}

In this case, it is not about applying to the magistrate, but about the selfemployed actions of the plaintiff (grabbing a certain thing of the debtor and keeping it to pay the debt). A person who had a claim to another person, in the case of non-payment, pronounced certain official words (which have not reached us), took the debtor's thing.

These actions were carried out without the participation of a public authority and, possibly, in the absence of the debtor himself. The latter circumstance essentially distinguishes the third form from the others. In any case, the seizure of things was accompanied by the proclaiming of verbal formulas, which testify to the legitimate grounds for seizure. The application of such actions was possible only with some religious or public demands, for example, when collecting animal fees sold for sacrifice or a soldier demanding from a treasurer to pay for military service.

\section{Legis actio per judicis postulationem.}

It should be noted that the corresponding place of Gaius's "Institutions" was lost. What is known about this form is only that during the in jure stage it was manifested in the request for appointment of a judge without sacramentum. It is believed that this form was used in cases where both parties were not sure of their righteousness and everyone was afraid of losing the sacramentum. The parties themselves had to first come to a certain agreement not to require each other to pay sacramentum. And this is possible only in conditions where the parties recognized the rights of each other, but without noticing their limits they apply to the court as an arbitrator to resolve the differences that arose between them. O. Joffe believes that the specified form of the process was used in the distribution of property and in other cases of the same type, for example, after the refusal of the defendant to pay the debt, the plaintiff stated: "If you refuse, then I ask you, praetor, that you give us a judge or an arbitrator".

According to M.H. Garcia Garrido, the emergence of this kind of claim has become progressive in the development of the Roman process ${ }^{7}$. This

6 Mommsen T. History of Rome / Vol. 1, second edition, stereotype. - Saint-Petersburg: "Nauka", 2005. - p. 176.

7 Garsia Garrido M. H. Roman Private Law: Cases, actions, institutions / Transl. from Spanish; editor L.L. Cofanov. - Moscow.: Statut, 2005. - p. 170. 
claim established the legal right of the parties to request the appointment of a judge or arbitrator. For the first time, such a lawsuit was referred to as a means of collecting debt from the template, as well as for distribution of inheritance. Litsinius Law of $210 \mathrm{BC}$ applied this particular suit for the division of a common thing.

\section{Legis actio per condictionem.}

The evidence on this form is such that it makes it possible to summarize only the general idea: the parties first appealed to the praetor about the appointment of a judge while his actual appointment took place after 30 days and the case moved from the stage in jure to the stage in judicio (I. 4. 18).

For what purpose this form was introduced and what specific needs it served remains unknown. There are no reports of either the old or the modern sources of anything definite about it. Even Gaius points out that it is unclear how to implement the legal process legis actio per condictionem:

As for claims on obligations, it was possible to use both legis actio per sacramentum and legis actio per judicis postulationem. Gaius reports that this form was introduced by two laws - lex Silia and lex Calpurnia (269 $\mathrm{BC})$. Legis actio per condictionem is the latest form and belongs to the Republican period. The law of Sylia established such a form for collecting a certain amount of money on demand, while by the law of Kalpurnia it was done for a certain item (Gaius I. 4.19).

These five forms formed the oldest Roman court procedure - legis actiones. It was in this form that it functioned in the first half of the republican period and is described us to Gaius. The first three forms of the process are adversarial because they result in a litigation between the plaintiff and the defendant. The last two forms can be called "executive", since their purpose was to ensure the effectiveness of a court decision or the exercise of a recognized right.

Summarizing briefly, it should be noted that, first, the legis actiones procedure showed the desire and the need to establish common rules for resolving a dispute between individuals. Whether in the law or in the agreement recognized by both parties to the dispute, there were established successive rules on which the case was considered by the court.

Secondly, the first legis actio are prototypes of modern procedural actions, for which the form, the content and their temporal limits are important. Each action must be clearly defined by pre-approved rules and implemented at a definite stage. These are the first forms of the requirements that relate to the form and content of procedural documents, as well as the procedural deadlines defined by modern procedural law. 
A characteristic feature of the legis actiones procedure is its division into two stages: in jure and in judicio. This is a reflection of the stages of modern proceedings in the case, each of which has its purpose and ensures the achievement of the result.

Proceedings in jure were carried out before the magistrate only in Rome at first, and then in prefectures, municipalities and colonies. It was held publicly on the square (comitium), before magistrate (pro tribunali). The judiciary was implemented by consuls and later by newly created magistrates - praetors.

Thirdly, litigation has always been associated with costs and Sacramento can be considered the first cost of legal proceedings, which was paid as a court fee for appealing to the court and was lost by the party which lost the case. But the actual court fee for appealing to the court is a novel of a later formulary procedure.

From ancient times Roman law limited individuals who frivolously treated the lawsuits in two ways: a fine or a holy oath.

At the same time, it is in Roman private law where we can see the development and changes that took place with the judicial processes during the time of the existence of the Roman state, analyze how the legal process is connected and dependent on the state structure and form of government.

In the first half of the period of the republic the legis actiones system continued to operate, but with certain additions and changes. Significant changes occurred in the process of legis actio per manus injentionem. If, according to the general rule, the debtor could not defend himself, then during the period of the republic certain laws provided for the right of the debtor to protect himself independently in certain cases (manum sibi depellere).

Despite some improvements, legis actiones more and more lacked the ability to meet the requirements of society and economic relations, which developed in the conqueror country quite quickly. The formalism of the procedure was kept and the slightest mistake in the formulation of the claim led to a loss. Therefore, appropriate litigation reform was necessary.

Most likely, the new form of the process, according to Y. Pokrovsky ${ }^{8}$ and C. Sanfilippo ${ }^{9}$ was borrowed from the process between the peregrinus, or from the process that was used in the provinces.

Consequently, since the times of Augustus, the legis actiones procedure remained in force only for inheritance cases, however, legis actio sacramenta, in jure cessio, manumissio, vindicta also remained in use.

8 Pokrovskyi I.A. History of Roman Law. - Moscow: Statut, 2004. - p. 175

9 Sanfilipo Chesare. Course of Roman Private Law: Textbook/ editor D.V. Dozhdev - Moscow.: Publishing house BEK, 2002. - p. 100 


\section{Kravtsov Serhij, Vlasenko Serhii, Rozhnov Oleh y Iryna Malinovska \\ 930

The formulary process put an end to rituals and the extreme formalism of the latter. The gestures and predefined words are replaced with the praetor formula from which this process takes its name. Just as the legis actiones, the formulary procedure consisted of two stages, but the stage in jure had its sole purpose of obtaining a praetor formula. M.H. Garcia Garrido notes that the typing of praetor written formulas led to the birth of a saying: "The way the formula is, such is the law"10.

The duty to formulate the subject of the dispute was transferred from the parties to the praetor. In the formulary process, the parties could express a case in any words and in any form before the magistrate, and it was the praetor who provided the claims of the parties with an appropriate legal form. From the explanations of the parties he deduced the legal essence of the dispute and described the essence in a special note to the judge, who was appointed to consider a particular case. This note was a formula, and since the moment it was received, it was considered to be the case of litis contestatio, and thus excluded the possibility of applying to the praetor to protect the same right, for the same reasons, in accordance with the rule of nie bis de eadem re sit action (the impossibility to initiate the same case twice).

All formulas were divided into civil and praetorial. Civil formulas reflected legis action and praetorial ones applied to new relationships.

The formula consisted of four mandatory parts (along with the mandatory part of appointing of a judge (judicis nominatio), for example, "Octavius judex esto" - Let Octavius be the judge)):

1) a statement of the circumstances from which the claim arises (demonstratio), for example, an indication that the claim originated from a debt obligation;

2) the formulation of the claim itself (intentio), which was carried out in the conditional form ("if it is true that Mucius must pay 100 sestertions" - "si paret Mutio sestertium centum dare oportere"). Intentio could have been different in nature, whether it was a matter of substantive law or a commitment. Depending on the situation, claims were divided into personal and tangible;

3) an order for the award of a clearly defined part of the property (adjudicatio), applied only in cases of division of joint property and the separation of borders;

4) an order for the award (condemnatio), if the claim is confirmed, looked like a continuation of the phrase relating to the previous part of the formula, if what is mentioned is confirmed, "the judge awards, 
and if not, then he denies the claim" (judex condemna, si non paret, absolve). When the dispute arose about the division of property, the last part of the formula was called not condemnatio, but adjudicatio: let it be sued as much as should be sued, (quantum adjudicare oportet, adjudicato). The content of this part could be different: with the indication of the amount, without indicating the amount or with the indication of the amount but with setting a certain maximum.

It should be noted that the formulas did not always contain four parts. Obligatory were judicis nominatio and intentio, because without a plaintiff's claim there would be no lawsuit.

The formula could also contain two auxiliary parts. The first of them was called exceptio (objection) and applied in cases where the defendant did not deny the claim, but his objections prevented its implementation (for example, the seller demanded payment of the purchase price and the buyer, without denying the fact of the contract, referred to the fact that the seller himself has not yet executed the contract - exceptio non adimpleti contractu).

The second auxiliary part of the formula was called praescriptio. A statement was introduced to restrict the plaintiff's right to the object of the dispute. For example, if a payment was to be made on a monthly basis, and the respondent had paid only one month, then the plaintiff may only claim unpaid payments.

Intentio (the subject of a claim) occupies a special place among the constituent parts of the praetorial formula. It is here that the praetor, along with the literal use of the old Quirith laws, applied to them a more modern interpretation or formulated new lawsuits. Over time, individual ways of protection, provided in the praetor formula to particular individuals in a particular case were subject to increasing typization with the assignment of their own names. Such, for example, claims for sold or purchased (actio venditi, actio empti), claims for recovery of the property by the owner (rei vindicatio) and others. The formula made in this way was an instruction for a judge who considered the case on the merits. It defined the limits of the trial.

The procedure of a formulary trial was as follows. When the parties appeared before the praetor, the proceedings began with the claimant filing a claim. The statement was addressed to both the praetor and the defendant. It was addressed to the praetor in order to ask him for the formula, and to the defendant to find out his position. If the defendant acknowledged the plaintiff's claim, the plaintiff received a claim of execution in the same way as if the process took place and the decision was made. But usually the defendant entered into a dispute, then a formula was made according to the procedure mentioned above. 


\section{Kravtsov Serhij, Vlasenko Serhii, Rozhnov Oleh y Iryna Malinovska \\ 932 \\ Legal procedure in roman law and its reflection in modern civil procedure}

In the formulary procedure, the notion of jurisdiction (or, in Latin, ius dicere "to say what is right") appeared. After setting the formula the proceeding before the magister was finished, this point is called litis contestatio.

The proceedings in judicio took place in the following manner. On the day chosen by the parties by mutual consent (but not later than 18 months - lex Julia), they should have appeared before the appointed judge for the second stage of the proceedings. According to general rules, the courts were represented by private judges or judices privati. Usually, private individuals (one is most often), three or five were appointed to be judges. The judge was appointed by the praetor, but the consent of the parties played the main role in the selection of a judge. Only if reaching agreement was impossible, the praetor appointed a judge of his choice.

The transition from the legis actiones procedure to the formulary one marked the development of new so-called praetorial methods of protecting private property rights, which opposed Quirith law. The most important of these methods were:

1. Praetorian stipulations (stipulationes pretoriae), the meaning of which was as follows. If the Quirith law required extremely complex forms of contract, then in the case of a mere promise to take certain actions given by one person to another before the praetor, the latter acknowledged this informal promise to be legally binding and enforced its execution in a compulsory manner. Praetorian templates could be used as a means of resolving a dispute between the parties. So, "if the damage is caused by the amount of 100 sesterces and the injured person is ready to pay it," the parties could legally draw up their relationship, appearing before the praetor and saying one phrase: the victim says: centum dare spondes? (do you promise to give 100?); the offender answers: spondeo (I promise). From the moment of the announcement of the said phrases, the obligation was considered to have arisen and was received compulsory protection from the praetor.

2. Introduction in possession (missio in possessionem). It could be extended not only to individual things (in rem), but also to property in general (in bona). The need for such a method arose, for example, in cases where a person, who was not considered to be the heir according to Quirith law, acquired inheritance rights under praetorian law. In these cases the praetor introduced it into the possession of hereditary property, thereby minimizing the rights of the Quirith heirs;

3. Restoration of the previous situation (restitutio in integrum). The Quirith law's formalism was manifested not only in the strict observance of the established procedure, but also in the fact that 
when it was observed, its legal consequences came irrespective of the real shortcomings of such a procedure. For example, if the seller rejected the property due to threat or violence from the buyer, then Quirith law did not take into account such circumstances. It adhered to the principle: coactus voluit tarnen voluit (wanted under coercion, but still wanted). In contrast to this the praetor in the presence of the injustice of the act, although formally and properly implemented, did not give it legal power and obliged to restore the situation that existed before the implementation of such an act (the parties returned the received property, the victim was compensated for damage, etc.);

4. Interdict (interdicta). Among the specific praetorial methods of protecting private property rights, interdicts had the most significant practical significance ${ }^{11}$.

If a certain fact was not reflected in the Quirith law, but the praetor considered it worthy of legal recognition, such recognition was ensured through an interdict, which the praetor, at the request of the person concerned, obliged the judge to make the appropriate decision upon confirmation of the circumstances mentioned by that person. Due to the interdicts, such an important institution of Roman law as the protection of possession was modelled, as well as other legal provisions that appeared in the formulary procedure.

In brief summary, it is worth mentioning the following. First, the formulary procedure became more complex and perfect. The inalienable procedural documents of legal proceedings, the prototype of a statement of claim, in which the subject matter of the dispute and court decision were formulated, appeared.

Secondly, with the introduction of the formulary procedure, access to judicial protection was simplified and representatives of the parties appeared.

And lastly, the list of means of proof expanded, and its rules became more understandable. Competition was provided by the right of parties to prove their correctness, and the impartiality of the judge was provided by the right to assess evidence.

\section{Cognitive (extraordinary) procedure}

In the classical era, along with the usual process, which was divided into two stages, jus and judicium, there were occurrences where disputed cases

11 Ioffe O.S., Musin V.A. The Fundamentals of Roman Civil Law. -Leningrad: Publishing House of Leningrad University. -1975 . - p. 24 


\section{Kravtsov Serhij, Vlasenko Serhii, Rozhnov Oleh y Iryna Malinovska \\ 934 \\ Legal procedure in roman law and its reflection in modern civil procedure}

were considered by the magistrate without transferring the case to a judge. Such a special, extraordinary procedure for dealing with cases was called extra ordinem and gradually became applicable in such categories of cases that were previously considered in the formulary process.

The grounds for applying in an extraordinary manner was the lack of protection in civil law and in the forms of ordinary litigation. In this case, the person could apply to the magistrate with a request to protect him by administrative means of power. If the magistrate considered the request worthy of attention, it itself solved the case, made a decision and executed it. This administrative review was called cognito or notion, and the process was called cognition extraordinarium.

During the republic period such a process was a rare event, its active development dates back to the era of the reign of Augustus and in the end of III century $\mathrm{AD}$, with the transition to an absolute monarchy it completely superseded the formulary process.

The reason was quite simple: in the conditions of the empire there was no confidence in elected judges - private persons - and to give them power to resolve disputes meant to divide the absolute power. Therefore, these functions began to be performed by imperial officials, and the judiciary gradually but finally moved from the hands of praetors to praefectus urbi (head of city police).

Cases were also personally considered by the imperial governors of the provinces - praesides or rectores. Since 294, the Emperor Diocletian issued an order to the rulers of the provinces to solve the cases by themselves, which secured extraordinaria cognitio as the only form of litigation.

Thus, the extraordinary process is the process of consideration of the case by the administrative bodies and officials appointed for the position.

Such changes significantly influenced both the principles and the procedure for dealing with cases. First of all, significant changes took place in the general principles of the trial. If in the ordinary proceedings the consideration of the merits and the judge's decision were based on the consent of the parties, then the whole process was built on the authorities' power and the decision was built on the order of authorities ${ }^{12}$.

The consideration of the case became public in nature and took place only in the presence of the parties and especially the venerable persons who had the right to be present at the consideration, which occurred indoors. If the plaintiff did not appear at the trial, the trial stopped. In the absence of the respondent, the case was considered in absentia. Almost everything that happened in the court was recorded in the judicial record. 
Finally, the process was not free: the parties of the dispute were required to make certain court fees for office expenses.

The procedure for summons to court changed. It was now officially involved with the participation of a government official. The plaintiff's complaint was filed with the court's report and then officially reported to the defendant. This method of summons to court was called litis denuntiatio.

The lack of division of the process into two stages led to the disappearance of litis contestatio. But since the moment of the trial had material and procedural consequences, for the sake of these consequences, litis contestatio refered to the moment the parties established a dispute, that is, when the plaintiff declared the defendant his claim in court, and the defendant expressed his intention to challenge it. After this, the judge began the examination of the case on the merits, verification of evidence, etc.

Proofs in the process were: testimony of the parties, testimony of witnesses, evidence of a documentary nature, expert assessments, presumptions ${ }^{13}$.

The acknowledgment of the parties was understood as the testimony given by the party overseen by the request of the other party. All that was said under oath was taken as truth.

Presumption as a means of proof was to relinquish the need to provide evidence in the event when facts were found from which the judge derided certain legal consequences: when the presumption could not be countered by any evidence; the presumption was admitted because the other party could not refute it with other evidence.

The role of witnesses was less significant. However, there were rules that determined the criteria for assessing witness testimony by judges. Witnesses were supposed to respond when the party requested it.

Proof of documentary character prevailed over testimony of witnesses. Government documents issued by officials were considered the most reliable type of evidence, since they were based on the authority of the state power. Documents drawn up by notaries were also considered to be reliable evidence if confirmed by the oath of notary. Documents of a private nature were of probative value only if they were confirmed by testimonies from at least three witnesses.

In this period the conclusions of experts-representatives of different professions (doctors, midwives, scribes) continued to be used. 


\section{6 \\ Kravtsov Serhij, Vlasenko Serhii, Rozhnov Oleh y Iryna Malinovska \\ Legal procedure in roman law and its reflection in modern civil procedure}

When the case was exhausted, the judge made his decision, lat. decretum. Now the decision did not necessarily have to formulate satisfaction of the claim in cash. It may have contained an order for enforcement in natura, the execution of which the defendant had to ensure.

Unlike the trial of the classical period in the cognitive process, an appellation of a resolution passed to a higher instance was admitted. Thus, complaints could be filed on the decision praefectus urbi: complaints on the decision of the ruler of the province were to be filed to the head of the imperial guard (praefectus praetorio), and complaints on his decision were to be filed to the emperor.

The procedure for lodging an appeal was as follows: it was filed in the same court where the decision was made by oral application "I am appealing", or in writing, through the submission of the so-called appellate plaque, within 2-3 days (10 days - according to the Newlines of Justinian), starting from the day when the parties learned about the court decision ${ }^{14}$.

The judgment, which was not challenged, was considered final after the expiration of the time limit for the appeal, and the process of its execution began. If the decision was appealed, then the execution was temporarily stopped ${ }^{15}$.

In addition to appellation (appeal), there were other means to cancel a court decision. In the cognitive process, the use of the restitution procedure considerably expanded. In particular, the restitution was applied if the decision was rendered on false evidence or if the judge made a decision as a result of a mistake, knowingly or threatened.

The court decision was appealed to the authorities by the request of the plaintiff. In the case of the awarding of the defendant the return of a certain thing, it was forcibly removed (manu militari) if, within two months, the defendant did not reject it voluntarily. If a sum was awarded, the bailiffs seized the defendant's amount or a certain thing sold for satisfaction of the plaintiff's claim. The recovery of all debtor's property took place only when claims were filed by several creditors of the debtor, while the debtor did not transfer the property voluntarily to their satisfaction.

The execution of decisions was now only the final part of the proceedings. In order to violate enforcement proceedings it was not necessary to file a separate claim (as it was in the formulary process), but rather a simple request from the party concerned.

14 Some of the following modern features of the appeal procedure we may find here, $O$ Uhrynouska 'Novelization of Civil Procedural Legislation of Ukraine in Cassation Review: Panacea or Illusion? (2020) 4(8) Access to Justice in Eastern Europe 209-225. 
Another kind of litigation became a specific form of the cognitive process, which under Justinian was called the libellar process. This name was given by the much more active development of written acts, libelli, than it had been before.

The beginning of such a process was the libellus conventionis or the petition. Thus, the process began with the filing of a claim - libellus conventions, which had to be filed with copies.

Having checked the formal correctness of the request, the court itself sent it through its contributing defendant with a proposal to appear at the specified time before the court. The runner had to obtain the provision of a valid appearance (cautio judicio sisti) from the respondent. Otherwise, the defendant could be arrested. If the defendant had objections to the claim, they were also laid out in writing, libellus contradictionis. The case was being processed in the same manner as before. The decision was also given in writing and now had the old name sentential. If the defendant did not appear in court, the proceedings continued in the form of an out-of-court process. The out-of-court process had serious procedural consequences. In this case, the defendant was no longer entitled to appeal the decision. He could hardly win the process and obtain a justifiable decision, since he could not refute the evidence provided by the plaintiff.

The liberal cognitive process was different from the previous ones in the issue of evidence. The means of proving were the same as in the extraordinary, but now the judge had the right to independently investigate, examine and obtain various evidence for using them in the course of the proceedings ${ }^{16}$. This is evidenced by the development of an inquisitorial model of legal proceeding ${ }^{17}$.

Also, the principle of limitation in assessing evidence was introduced: now the judge could not investigate the evidence at his own discretion but should have been guided by legislative acts.

These changes in the post-classical process were significant but they were unlikely to indicate the emergence of a new process. All characteristic features of the cognitive process were preserved.

Summarizing, it is worth mentioning the following. The transition to an extraordinary process of cognition indicates a significant impact of the state and state bodies on judicial activity.

16 See more about modern sources of a judge power in investigation of facts in Izarova Iryna, SzolcNartowski Bartosz, Kovtun Anastasiia Amicus Curiae: Origin, Worldwide Experience and Suggestions for East European Countries Hungarian Journal of Legal Studies Vol. 60, No 1, 2019, Pp. 18-39. 10.1556/2052.2019.60.1.3

17 Izarova Iryna, Flejszar Radoslaw Summaries of the conference "Small claims procedure: the European and the Ukrainian experience" in Access to Justice in Eastern Europe, 2018, Issue 1, Pp. 81-84. 


\section{8 \\ Kravtsov Serhij, Vlasenko Serhii, Rozhnov Oleh y Iryna Malinovska \\ Legal procedure in roman law and its reflection in modern civil procedure}

First and foremost, the formation of a bureaucratic apparatus of officials that implemented judicial power led to the emergence of professional judges who were familiar with the proceedings, as well as the law applicable to the resolution of the dispute. On the other hand, the combination of the functions of the administrative executive power and the judiciary negatively affected the procedure for the administration of justice as it led to the disappearance of such elements as the publicity and veracity of the process and led to the secrecy of the consideration of the case.

The introduction of such new institutions as an appeal, which allowed to correct court errors, is also of significant importance.

\section{Conclusions: On the impact of Roman law on the regionalization of the civil process in modern Europe}

For centuries general principles and rules for the administration of justice were established in Roman private law. They relate not only to procedural law, but also to the legal status of judges and the judiciary in general. The relationship between the court system and the judicial process is evident precisely on the example of Roman litigation.

At the time of the occurrence of the first trials there was the formation of their main principles, general provisions, which play an important role today. These are the ideas of equality of everyone before the law and the court, openness and publicity of the administration of justice, adversarial, compulsory court decision, etc., which became traditional in the idea of the administration of justice in European civilization ${ }^{18}$.

Among the basic principles of the Roman lawsuits, which became the general foundations of the modern European civil process, one should distinguish the following:

1. the main purpose of the trial is to resolve the dispute by establishing, by means of evidence, the circumstances of the case, determined by the requirements of the plaintiff and objections of the defendant;

2. the consideration of the case occurs through the implementation of certain and orderly procedural steps, which are carried out in stages, binding to all participants and the court;

3. publicity and openness, which were realized with the help of a single language of legal proceedings; 
4. the claim is a means of initiating the process; accordingly, determinative for the civil process is the principle of discretion; the dynamics of the process in the future depends on the presence of the plaintiff;

5. the parties of the process are both parties: the plaintiff and the defendant, who in the adversarial process prove their rightness; in conjunction with the idea of equality of rights of the parties, which was reflected in the first table of the laws of the Twelve Tables; these principles became one of the most evolutionary achievements of Roman law;

6. the case ends with the adoption of a decision for the implementation of which there is a special procedure, since judicial proceedings are not aimed at persons who seek protection of their rights.

The regionalization of the civil process in modern Europe testifies the importance and necessity of addressing the general principles of legal proceedings. The idea of creating a unified European code of civil process 19 is updated with a more in-depth study of the foundations of Roman litigation. The idea of creating a unified European code of civil process is updated with a more in-depth study of the foundations of Roman litigation.

\section{Bibliographic References}

ARISTOTLE Politics.2005. Aristotle; transl. in Russian by S.A. Zhebelev, M.L. Gasparova.ACT: Transitkniga,. pp.237.

CIVIL Litigation in a Globalizing World.2012.eds.: X. E. Kramer, C. H. van Rhee. Hague.Asser Press,.

EUROPIAN Traditions in Civil Procedure.2005. ed:. C. H. van Rhee. Oxford. Intersentia Antwerpen,.\# XVI, pp.344.

GAIUS Institutions In: http://thelatinlibrary.com/law/gaius.html.Date of consultation: 14/09/2O2O

GARSIA Garrido M. H. 2005.Roman Private Law: Cases, actions, institutions. Transl. from Spanish; editor L.L. Moscow.pp. 170.

IZAROVA I., Silvestri E. 2018.Case management principle in civil justice: a comparative study of the legislation of Italy and Ukraine .Bulletin of Taras Shevchenko National University of Kyiv. Vol. 1 (106).pp. 19-23. (In Ukrainian)

19 Report with recommendations to the Commission on common minimum standards of civil procedure in the EU, Committee on Legal Affairs, o6 June 2017 http://www.europarl.europa.eu/sides/getDoc. do?pubRef=-//EP//TEXT+REPORT+A8-2017-0210+o+DOC+XML+Vo//EN 
Kravtsov Serhij, Vlasenko Serhii, Rozhnov Oleh y Iryna Malinovska
$940 \quad$ Legal procedure in roman law and its reflection in modern civil procedure

IZAROVA Iryna.2017. On the Way to European Integration: Main Trends of the Reform of Civil Procedure Code in Modern Ukraine.Kieler OstrechtsNotizen. Vol. No1/2017. Pp. 17-25.

IZAROVA Iryna.2019. Reform of Civil Justice in Ukraine: A Differentiation of Action Proceedings and Review of Court Decisions. Teise (Law), Vol. 111 pp. 234-245.

IZAROVA Iryna, 2019. Szolc-Nartowski Bartosz, Kovtun Anastasiia Amicus Curiae: Origin, Worldwide Experience and Suggestions for East European Countries Hungarian Journal of Legal Studies Vol. 6o, Pp. 18-39.

IZAROVA Iryna .2019. Strengthening Judicial cooperation in civil matters between the EU and neighboring countries: the example of Ukraine and the Baltic states Baltic Journal of Law \&Politics, Volume 12, \# 2, pp. $115-133$.

IZAROVA Iryna.2014.Judicial Reform of 1864 on the Territory of the Ukrainian Provinces of the Russian Empire and Its Importance for the Development of Civil Proceedings in Ukraine.Russian Law Journal, , Vol. II, pp. 114-128.

IZAROVA Iryna, Flejszar Radoslaw.2018.Summaries of the conference "Small claims procedure: the European and the Ukrainian experience". Access to Justice in Eastern Europe, Issue 1, pp. 81-84.

MOMMSEN T. History of Rome.2005. Vol. 1, second edition, stereotype.SaintPetersburg: "Nauka".pp. 176.

UHRYNOVSKA O.2020. 'Novelization of Civil Procedural Legislation of Ukraine in Cassation Review: Panacea or Illusion.Access to Justice in Eastern Europe. pp.209-225.

POKROVSKYI I.A. 2004. History of Roman Law. Moscow. Statut,. pp. 101

RUDENKO, M., MALINOVSKA I., KRAVTSOV S.2021. Justice for judges in Ukraine: Looking for peace and strong judiciary institutions in a sustainable society. European Journal of Sustainable Development, Vol:10 (1). pp. 339-348.

PRYTYKA Y., KOMAROV V., KRAVTSOV S. 2021. 'Reforming the Legislation on the International Commercial Arbitration of Ukraine: Realities or Myths'. Access to Justice in Eastern Europe. Vol: 3(11). pp: 117-128

SANFILIPO Chesare. Course of Roman Private Law: Textbook/ editor D.V. Dozhdev - Moscow.: Publishing house BEK, 2002. - p. 100 
STORME M. A. 2005. Single Civil Procedure for Europe: A Cathedral Builders' Dream. Ritsumeikan Law Review.. In: http://www. asianlii.org/jp/journals/RitsLRev/2005/6.pdf

PEDRO Luis Bracho Fuenmayor. Justicia desde la óptica de John Rawls y Robert Nozick: una perspectiva comparada. In: https:// produccioncientificaluz.org/index.php/cuestiones/issue/view/ cuestpol.3970.00/272 

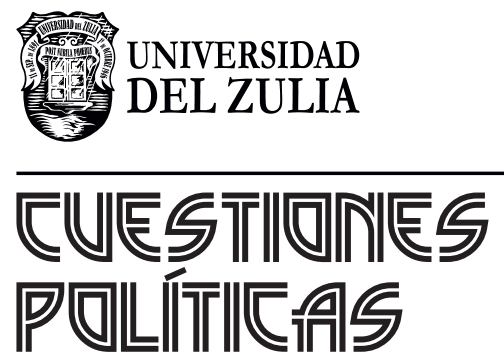

Vol. 39 N $^{\circ} 71$

Esta revista fue editada en formato digital y publicada en diciembre de 2021, por el Fondo Editorial Serbiluz, Universidad del Zulia. Maracaibo-Venezuela 